Smoge, G.Y., Torp, O., and Johansen, A. 2020. "Maturity of TVD Implementation in Norwegian Public Building Projects." In: Tommelein, I.D. and Daniel, E. (eds.). Proc. $28^{\text {th }}$ Annual Conference of the International Group for Lean Construction (IGLC28), Berkeley, California, USA, doi.org/10.24928/2020/0087, online at iglc.net.

\title{
MATURITY OF TVD IMPLEMENTATION IN NORWEGIAN PUBLIC BUILDING PROJECTS
}

\author{
Gard Y. Smoge ${ }^{1}$, Olav Torp ${ }^{2}$, and Agnar Johansen ${ }^{3}$
}

\begin{abstract}
There is an emerging international interest in the Architecture, Engineering and Construction (AEC) industry towards designing and constructing building projects based on Target Cost (TC) through the development of 'Target Costing' and Target Value Design (TVD) ${ }^{4}$. The aim is to create more value for the client and the users through iterative design processes focusing on optimization of value within cost limitation.

The purpose of this study is to discover and bring awareness of the maturity of TVD implementation during the pre-project phase in Norwegian public building projects. Findings in the research are a result of a literature study and five case studies which included a document study and semi-structured interviews with the involved project managers (PMs) from both the client and the contractor. The case studies provide the current maturity of TVD implementation during the pre-project in a number of Norwegian public building projects and shows that the TVD characteristics are only partially implemented. TVD maturity varies across the categories: contracting, organizing, defining (business case and validation) and steering. Furthermore, enhancing maximum project value is a challenge due to the lack of visualization and the focus towards cost reduction.
\end{abstract}

\section{KEYWORDS}

Target Value Design, Target Value Design Maturity, Target Cost, Collaboration

\section{INTRODUCTION}

'Target Costing' is a management practice in new product development and manufacturing industries focusing on predictable profit planning by meeting market determined prices (Feil et al. 2004). TVD is a lean construction method that has gained increased popularity over the years, especially in Integrated Project Delivery (IPD) type of projects (Tillmann et al. 2017). The origin of TVD can be tracked back to Target Costing. Though, the iterative process of evaluating value and purpose in design against constraints predefined in the business case distinguish TVD from other managerial tools (Ballard and Pennanen 2013; Chen et al. 2014; Namadi et al. 2017).

1 MSc student, NTNU - Norwegian University of Science and Technology, Trondheim, Norway, +47975 31 662, gardys@stud.ntnu.no, orcid.org/0000-0003-3666-2885

2 Associate Professor, NTNU - Norwegian University of Science and Technology, Trondheim, Norway, +47934 226 73, olav.torp@ntnu.no, orcid.org/0000-0002-1916-5097

3 Professor, NTNU - Norwegian University of Science and Technology, Trondheim, Norway, +47 93058 741, a.johansen@ntnu.no, orcid.org/0000-0003-0063-3679

4 Some scholars use the acronym "TVD" for Target Value Delivery. 
Cost increase through the planning and construction of Norwegian construction projects is a challenge (Ulstein et al. 2015; Torp et al. 2016; Bakke et al. 2019). Ulstein et al. (2015) discovered a $55 \%$ cost increase between the choice of concept and the execution phase in four projects due to direct, underlying and systematic/organizational causes. Torp et al. (2016) revealed a $50 \%$ cost increase during the planning phase in 11 large and 34 medium sized projects. Moreover, 19 governmental projects experienced a $30 \%$ cost increase from pre-design and to completion (Bakke et al. 2019).

TVD has received an emerging interest among researchers and practitioners towards avoiding cost overruns and adding value. Previous research have shown that TVD projects are completed 15-20\% below Market Cost (MC) while maintaining quality and time (Ballard and Rybowski 2009; Zimina et al. 2012). Furthermore, the use of the method increased the accuracy of conceptual estimates (Ballard and Pennanen 2013) and lowered the contingency needed for each project (Zimina et al. 2012; Chen et al. 2014). The method also helped to manage complexity and prevent 'overdesign' (Lee et al. 2012) by focusing on common goals and objectives (Namadi et al. 2017).

This study will elaborate on the current state of TVD implementation in Norwegian public building projects. The purpose of the research is to discover and bring awareness of the maturity of TVD implementation during the pre-project phase. One research question (RQ) is of special interest:

- RQ: How is the TVD maturity in the Norwegian Construction Industry?

\section{METHOD AND RESEARCH DESIGN}

An initial literature review justifies the research question and brings an understanding of the research perspective. Back- and forward searches were based on the Credibility, Objectivity, Precision and Suitability (TONE)-framework. This ranking provides transparency and an evaluation of 'reliability' and 'validity'.

Qualitative sampling must consider both the appropriateness and the adequacy of the data. Qualitative methods provide value through the concept of triangulation (Creswell 2003), which may result in a multiplication of the potential to discover unanticipated outcomes. Yin (2018) stated that case study is a relevant research approach when investigating 'how' or 'why' RQs. In total, five cases are explored in-depth based on document studies of internal documents (steering document, pre-project report, monthly reports etc.) and semi-structured interviews with the PMs representing both the client and the contractor. In total six 1,5-2 hour interviews have been conducted.

Based on the theory and the literature review a structured scorecard containing the TVD characteristics has been developed. Table 1 provides a brief case description. Each case has based on interviews and the document study been ranked according to their current TVD implementation of these characteristics.

\section{THEORETICAL FRAMEWORK}

A project model consists of phases and decision gates. A simple project model goes through the phases planning, design, construction and use. Figure 1 illustrates the Oslo municipality's project model, where the planning phase is divided into Initiation; Choice of Concept Evaluation; Choice of Concept; Pre-project, followed by the political decision to start design and construction. The focus of this research is the pre-project. 
Table 1: Case study: Brief project description

\begin{tabular}{|l|l|}
\hline Case 1 & $\begin{array}{l}\text { Case Description } \\
\text { Part of a larger public development plan to encounter growth within the municipality. } \\
\text { Demolition and construction of a new high school (550 pupils) and a swimming pool. } \\
\text { Partnering contract. }\end{array}$ \\
\hline Case 2 & $\begin{array}{l}\text { Part of the same larger development plan as case 1. Constructing a new elementary school } \\
\text { (700 pupils), a sports center with a tribune (300 people) and two swimming pools. Involves } \\
\text { the same contractor as case 1. Partnering contract. }\end{array}$ \\
\hline Case 3 & $\begin{array}{l}\text { Part of a master plan to upgrade 2,500 of the municipality's nursing home spots. } \\
\text { Construction of 144 spots, a senior and a day care center. First BREEAM Excellent certified } \\
\text { nursing home in the country. }\end{array}$ \\
\hline Case 5 4 & $\begin{array}{l}\text { Part of the same master plan as case 3. Demolition and construction of a new 6-storey } \\
\text { BREEAM Excellent and Zero Emission Building (ZEB) building with 144 new spots. } \\
\text { Resulting in the most environmental-friendly nursing home in the country. }\end{array}$ \\
\hline $\begin{array}{l}\text { Part of the same development plan as case 1 and 2. Constructing a sports center with the } \\
\text { stated purpose to achieve the local sports community's wanted functions. The design } \\
\text { competition was cancelled due to not satisfying the users' needs. Further, the contract was } \\
\text { changed from combining partnering and design-build to a full design-build contract. }\end{array}$ \\
\hline
\end{tabular}

Initiation $\left.\left.\sum \begin{array}{c}\text { Choice of } \\ \text { Concept } \\ \text { Evaluation }\end{array}\right\rangle \begin{array}{c}\text { Choice of } \\ \text { Concept }\end{array}\right\rangle$ Pre-project $\left.\left.\ \begin{array}{c}\text { Political } \\ \text { evaluation/ } \\ \text { decision }\end{array}\right\rangle \begin{array}{c}\text { Design and } \\ \text { Execution }\end{array}\right\rangle$ Delivery

Figure 1: Public construction projects within the Oslo municipality follows this project model (Samset et al. 2015).

Using standardized solutions provide an opportunity to apply 'Target Costing' which results in a portfolio of proven design that reflect reasonable price, cost and time estimates (Pennanen et al. 2010). Zimina et al. (2012) claimed that the focus of target costing is cost rationalization and not minimization. Allowable cost (AC) is the amount the customer is willing and able to pay for a facility with defined performance. Expected cost (EC) on the other hand corresponds to the cost for a facility with determined performance provided at current best practice. Together they provide the basis of design. The essence of designing to cost targets is to let the design converge to cost rather than the other way around (Pennanen et al. 2010). Set-based design (SBD) prioritize to choose design alternatives in the 'last responsible moment' which enables the project to achieve cost targets (Ballard and Rybkowski 2009; Lee et al. 2012) by involving the design team

Zwikael and Smyrk (2012) defined 'benefit' as the "flow of value" which is based on target outcome realization. 'Outcome' is: "(...) a desired, measurable end-effect that arises when the outputs from a project are utilized by certain stakeholders." Serra and Kunc (2015) described benefits as: "(...) increments in the business value from not only a shareholders' perspective but also customers', suppliers', or even societal perspectives."

Researchers have recently shifted their focus towards benefit-oriented project management. Chih and Zwikael (2014) demonstrated that projects are becoming value creation processes and success exceeds output-measures like time, cost and quality.

Tillmann et al. (2017) reported that factors that influence the ability to deliver a project to target costs are 1) how cost targets are set and market price is estimated, 2) how shared profit is agreed upon and made transparent and 3) how production costs are steered towards the target cost and tracked, so risks can be identified and mitigated. In the preproject phase, how to estimate the cost/set targets and how shared profit is agreed upon is relevant. The following section considers how to estimate cost. 


\section{COST ESTIMATION}

A cost estimate is: “(...) the identification and consideration of costing alternatives to initiate and complete the project" (PMI 2013). Main features of project models are cost estimation and uncertainty analysis (Welde et al. 2015). Nguyen et al. (2008) discussed different types of cost models such as parametric cost and unit price estimates. Cost estimates are forecasts and therefore always uncertain. 'Cost drivers' are defined by Klakegg et al. (2018) as premises and/or decisions that affects the investment and operation cost. 'Value drivers' are functional attributions necessary for delivering expected project benefit. Ballard and Morris (2010) defined six cost drivers when analyzing and targeting cost reduction measures during the design phase: proactive value engineering; scope control; grounding scope in business purpose, aligned with constraints; steering design to targets; scope refinement. Having knowledge of both cost and value drivers provides the possibility to use and control the decision-making towards maximizing value within project constraints. Addressing and managing the uncertainty is needed to steer towards Target Cost. Zimina et al. (2012) highlighted the need to distinguish between different types of clients in regard of cost planning: 1) Client/Developers: cost target is derived from the business case which is clearly profit oriented, and 2) Public clients and clients doing self-construction: Allowable Cost can be set by developing the business case based on financial constraints, end-customer and organizational value. A validation of the business case will determine the Expected Cost.

Firstly, determine a variety of baseline buildings. Then secondly, based on the baseline buildings, identify target building systems. Altogether this determines the Allowable Cost in the business case. This benchmarking process uses historical information which must specify project-specific elements in order to achieve a realistic maximum project cost. Torp (2019) concluded that stochastic estimates can be applied for setting Allowable Cost (P85) and estimating Expected Cost (P50).

\section{TARGeT VALUe Design}

TVD is a management method targeting to maximize the value for the client and user within project constraints (Ballard 2008). Ballard and Morris (2010) characterized TVD as the relationship between Expected Cost and Allowable Cost with key features such as "design to targets" to increase predictability. Focus on the shared understanding and collaboration about the project basis has proven to be beneficial (Lee et al. 2012). Moreover, the study further explored the "conceptualization of design processes" which describes TVD as a lean design management method. Namadi et al. (2017) described, based on the identified findings in the literature, five TVD characteristics:

Table 2: Five characteristics for TVD from Namadi et al. (2017)

\begin{tabular}{|l|l|}
\hline Characteristics & Description \\
\hline Target costing setting & $\begin{array}{l}\text { Instead of estimating based on detailed design, the concept focuses more on } \\
\text { detailed estimate. } \\
\text { Instead of designing and then converging later for group reviews and } \\
\text { decisions, the concept emphasize on working together to define the issues, } \\
\text { produce decisions then design to those decisions. }\end{array}$ \\
\hline Co-location & $\begin{array}{l}\text { Instead of working in silos and separate rooms, the method advocates } \\
\text { working in pairs or large groups and face to face. }\end{array}$ \\
\hline Set-based design & $\begin{array}{l}\text { Rather than narrow choices to proceed with design, it allows several } \\
\text { alternative solutions to proceed far into the design process. }\end{array}$ \\
\hline Work Structuring & $\begin{array}{l}\text { Instead of evaluating the constructability of a design one should designing } \\
\text { what is constructible. }\end{array}$ \\
\hline
\end{tabular}




\section{DETERMINATION OF TVD MATURITY}

In order to determine the TVD maturity and to answer the RQ, a scorecard has been developed based on identified TVD characteristics in cited and well-known articles investigating TVD (Ballard 2008; Pennanen and Ballard 2008; Ballard and Morris 2010; Lee et al. 2012; Zimina et al. 2012; Denerolle 2013; Namadi et al. 2017).

A TVD 'characteristic' is an element or an activity which has been identified in the literature to be a part of the TVD process. Several of the repeated characteristics were adapted and merged within the four categories: contracting, organizing, defining (distinguished between the business case and validation) and steering. Three TVD categories arose based on findings in Denerolle (2013), while the contracting element was added based on statements from the interviewees. A natural development of the preproject aligns the four categories chronologically. Meaning, that the characteristics within the 'Organizing' category are reliant on the fulfilment of the previous one in order to be fully implemented. Table 3 illustrates a structured overview of the TVD characteristics.

Table 3: Summary of TVD characteristics based on findings in the stated literature

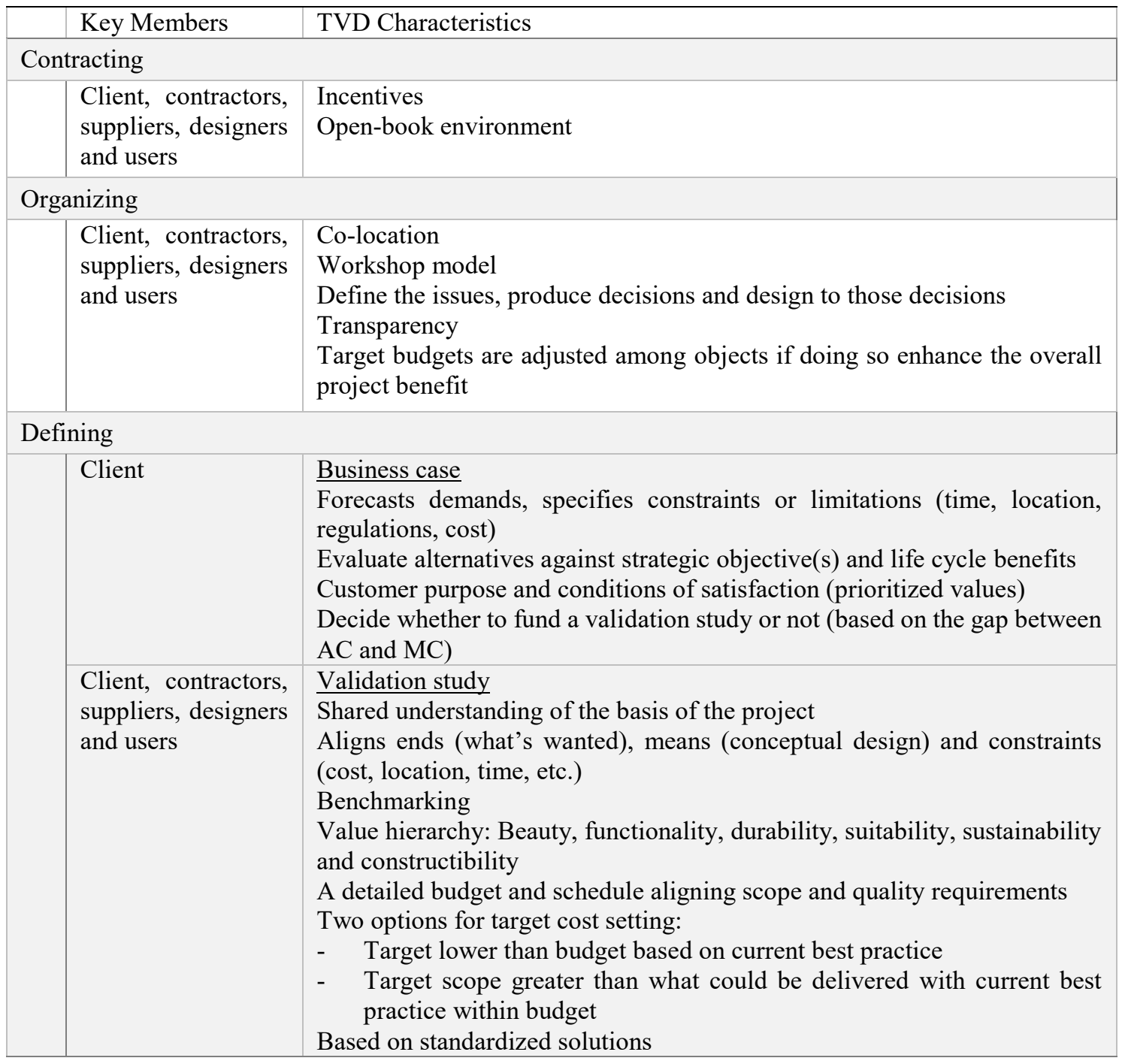




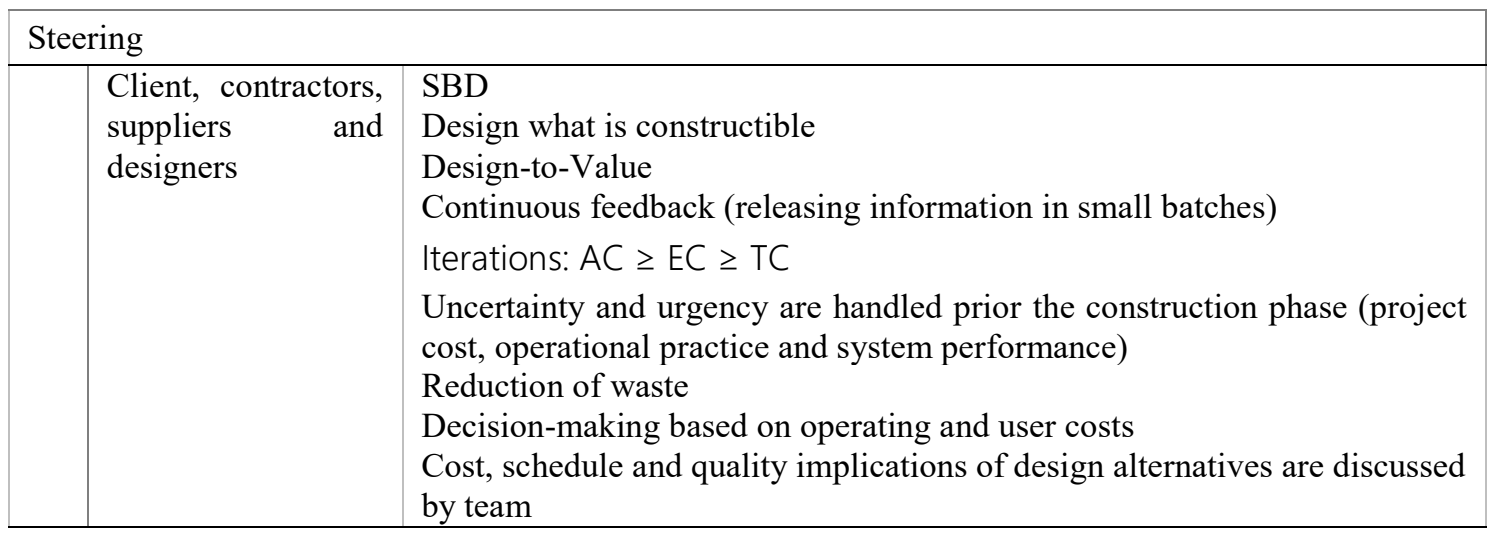

\section{CASE STUDY}

Each of the explored cases have their own attributes. A brief summary of the five cases is provided in Table 4. Figure 2 illustrates the Expected Cost development as reported in the monthly reports from the PM to the client. The current project progress is not differentiated based on actual time left before project delivery. Each phase starts at the marked line which is differentiated between the pre-project that starts once the contractor has signed the contract while the design and execution phase begins once the steering document is delivered to political evaluation and verification by external consultants.

Table 4: Summary of the cases used in the study

\begin{tabular}{|l|l|l|l|l|l|l|}
\hline Project & Completion & Size $\left[\mathbf{m}^{2}\right.$ ] & Cost & Time [months] & Contract & Type \\
\hline Case 1 & $\begin{array}{l}\text { Autumn } \\
2020\end{array}$ & 7913 & 36.0 MUSD & $\begin{array}{l}\text { Planning: 5.5 } \\
\text { Execution: } 27\end{array}$ & Partnering & $\begin{array}{l}\text { New } \\
\text { building }\end{array}$ \\
\hline Case 2 & $\begin{array}{l}\text { Winter } \\
2021\end{array}$ & 13750 & 70.8 MUSD & $\begin{array}{l}\text { Planning: } 11.5 \\
\text { Execution: } 30\end{array}$ & Partnering & $\begin{array}{l}\text { New } \\
\text { building }\end{array}$ \\
\hline Case 3 & $\begin{array}{l}\text { Autumn } \\
2017\end{array}$ & 16238 & 73.2 MUSD & $\begin{array}{l}\text { Planning: 16,5 } \\
\text { Execution: } 24\end{array}$ & Design-Build & $\begin{array}{l}\text { Renovation } \\
\text { and new } \\
\text { building }\end{array}$ \\
\hline Case 4 & $\begin{array}{l}\text { Summer } \\
2020\end{array}$ & 9120 & 77.0 MUSD & $\begin{array}{l}\text { Planning: 10 } \\
\text { Execution: 33 }\end{array}$ & $\begin{array}{l}\text { Partnering and } \\
\text { Design-Build } \\
\text { Wew } \\
\text { building }\end{array}$ \\
\hline Case 5 & 3394 & 20.3 MUSD & $\begin{array}{l}\text { Planning: 5 } \\
\text { Execution: } 20\end{array}$ & Design-Build & $\begin{array}{l}\text { New } \\
\text { building }\end{array}$ \\
\hline
\end{tabular}

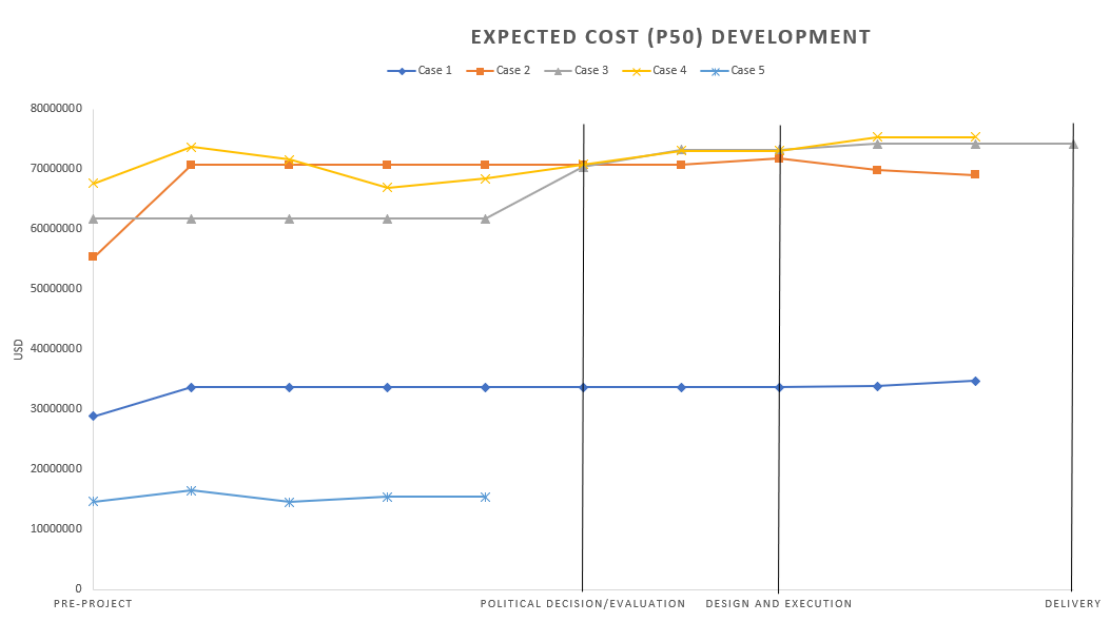

Figure 2: Expected cost (P50) development for the five case. Case 3 is the only one that is finished while case 5 is the project with the least progress 


\section{TVD IMPLEMENTATION}

Based on the developed scorecard ranging from 0 (not implemented) to 3 (fully implemented) a ranking of the TVD characteristics has been conducted. The results are illustrated in Table 5. Figure 3 displays the average score (AS) for case 4 and 5 and visualize the difference of TVD maturity between the investigated cases.

Table 5: Ranking of TVD implementation for each of five cases based on scorecard

\begin{tabular}{|c|c|c|c|}
\hline Project & TVD characteristics & Description & $\mathrm{AS}$ \\
\hline \multirow[t]{5}{*}{ Case 1} & Contracting & Partnering, 50/50 split. & 3 \\
\hline & Organizing & $\begin{array}{l}\text { Limited collaboration and co-location, no target } \\
\text { budgets among project objects. }\end{array}$ & 1.5 \\
\hline & Defining (business case) & $\begin{array}{l}\text { Validation not based on AC, no priority of outputs, } \\
\text { specifying demands, constraints and limitations. }\end{array}$ & 2 \\
\hline & Defining (validation study) & $\begin{array}{l}\text { Shared understanding, align ends, means and } \\
\text { constraints, target scope greater than best practice. }\end{array}$ & 2 \\
\hline & Steering & $\begin{array}{l}\text { "Nice to have vs. need to have", targeting cost } \\
\text { drivers, rejected optimizations due to cost. }\end{array}$ & 2.5 \\
\hline \multirow[t]{5}{*}{ Case 2} & Contracting & Partnering, 50/50 split. & 3 \\
\hline & Organizing & $\begin{array}{l}\text { Limited collaboration and co-location, no target } \\
\text { budgets among project objects. }\end{array}$ & 1.5 \\
\hline & Defining (business case) & $\begin{array}{l}\text { Validation not based on AC, no priority of outputs, } \\
\text { debated project location. }\end{array}$ & 1.5 \\
\hline & Defining (validation study) & $\begin{array}{l}\text { Shared understanding, align ends, means and } \\
\text { constraints, no benchmarking, target budget lower } \\
\text { than best practice. }\end{array}$ & 2 \\
\hline & Steering & Limited SBD, focus towards cost reduction. & 2 \\
\hline \multirow[t]{5}{*}{ Case 3} & Contracting & Design-build, possibility to cancel the project. & 1 \\
\hline & Organizing & $\begin{array}{l}\text { Limited collaboration, transparency, workshop } \\
\text { model. No target budgets for project objects. }\end{array}$ & 1 \\
\hline & Defining (business case) & $\begin{array}{l}\text { Validation not based on AC, part of a master plan, } \\
\text { priority of sustainable alternatives. }\end{array}$ & 2.5 \\
\hline & Defining (validation study) & $\begin{array}{l}\text { Limited understanding, target scope greater than best } \\
\text { practice, not standardized solutions. }\end{array}$ & 1.5 \\
\hline & Steering & Limited SBD, project goals, design-to-value. & 2.5 \\
\hline \multirow[t]{5}{*}{ Case 4} & Contracting & $\begin{array}{l}\text { Partnering during pre-project, design-build, } \\
\text { possibility to cancel the project. }\end{array}$ & 2 \\
\hline & Organizing & $\begin{array}{l}\text { Limited co-location, not fully implemented } \\
\text { workshop model, four contractual milestones. }\end{array}$ & 2 \\
\hline & Defining (business case) & $\begin{array}{l}\text { Validation not based on AC, part of a master plan, } \\
\text { priority of LCC for alternatives. }\end{array}$ & 2.5 \\
\hline & Defining (validation study) & $\begin{array}{l}\text { Target scope greater than best practice, limited } \\
\text { benchmarking and standardized solutions. }\end{array}$ & 2 \\
\hline & Steering & $\begin{array}{l}\text { Challenging current best practice, project goals and } \\
\text { focus on operation cost. }\end{array}$ & 2.5 \\
\hline \multirow[t]{5}{*}{ Case 5} & Contracting & Design-build, no incentives. & 0 \\
\hline & Organizing & $\begin{array}{l}\text { Limited co-location, transparency, single user with } \\
\text { influence. }\end{array}$ & 1 \\
\hline & Defining (business case) & $\begin{array}{l}\text { Validation not base on } \mathrm{AC} \text {, condition of satisfaction } \\
\text { not matching target budget. }\end{array}$ & 1.5 \\
\hline & Defining (validation study) & $\begin{array}{l}\text { Limited understanding, mismatching ends and } \\
\text { constraints, no benchmarking. Standardized } \\
\text { solutions. }\end{array}$ & 1.5 \\
\hline & Steering & $\begin{array}{l}\text { No SBD, constructible design, single user's } \\
\text { expectations, uncertainty. }\end{array}$ & 1.5 \\
\hline
\end{tabular}



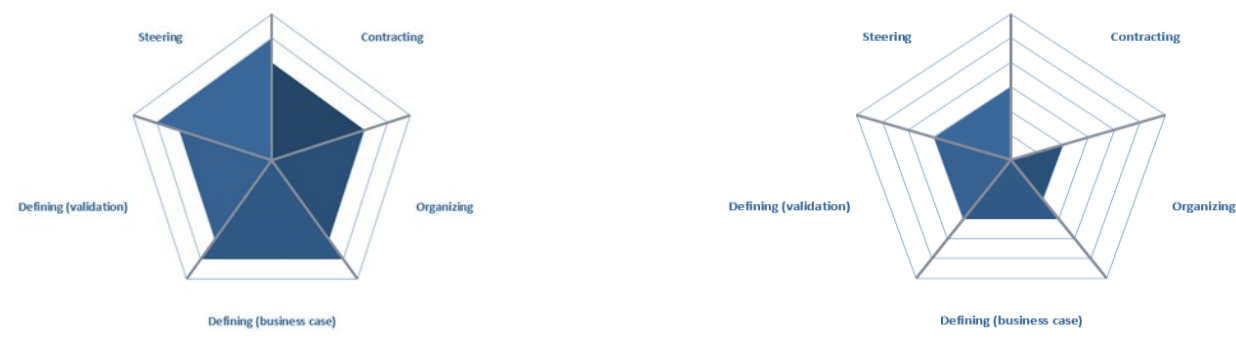

Figure 3: Maturity of TVD implementation for case 4 (left) and case 5 (right)

\section{DISCUSSION - IMPLEMENTATION OF TVD CHARACTERISTICS}

Both the "Contracting" and "Organizing" characteristics create the foundation of which the "Defining" elements are based on. This is an iterative process conducted by the client and during the validation study, conducted alongside the contractor, sub-contractors and -suppliers, designers and user(s). "Steering" is meant to keep track of the iterative process, adjust and control the elements of surprise.

\section{Contracting}

Contracting elements create the foundation of which a fully TVD implementation must be based on. In order to completely utilize the competence among the contractors and the designers to maximize project value, the contractual arrangements are a necessity. There is a need for incentives in order to achieve necessary focus towards the project as an entirety. Case 1 and 2 practice a 50/50-split of the optimized savings between the client and the contractor. In case 4 the PM challenged the contractor to chase and modify the environmental targets by offering additional payment. Though, as pointed at in case 3 , the human relation differs between project organizations independently of contractual arrangements. A change of personnel weakens the relations and reduces the knowledge obtained during the development. Consistency is important for the close collaboration between the project organization and to fully exploit the optimization process. Especially in regard of key decision-makers. Defining the difference between a 'change' and an 'optimization' in order to avoid uncertainty seems to be significant. TC can be based on established contracts with sub-contractors and -suppliers which complicates the split.

\section{Organizing}

Besides from case 5, which had a twisted turn during its project development, every case use, or at least stated that they should use, collaborative methods. One element in the collaborative environment besides having the possibility for co-location, is to define issues, produce decisions and design to those decisions. Meaning, that the project organization is supposed to make weighted interdisciplinary decisions to create the most beneficial solution to maximize project value. A prerequisite for this assumption is that necessary decisions-makers are involved in these meetings. Case 3 and 4 differs from 'ordinary' public construction projects by granting the PM decision-making authority. As stated in the interviews, this authority provided the PM the ability to make rapid decisions alongside legitimizing the power and the responsibility needed for this position. The purpose of having interdisciplinary meetings is to make collaborative decisions. But, as stated by the interviewee, the users started to make decisions without properly visualizing the consequences of these decisions. Often these decisions had economically effects and 
changes could easily occur based on short-term solutions on arising project issues. Therefore, the project proceeded with separated user meetings. On the other end of the scale is case 5. Case 5 is an example of the consequences for the client if not obtaining the full decision-making authority. Political influence created a path for the user to sway the municipality as the client. Different expectations have not been aligned which resulted in delays and reduction of project scope.

\section{Defining (Business case)}

Characteristics of defining the business case is closely related to the evaluation of choice of concept process within the Oslo municipality investment regime: Involves evaluation of alternatives, prioritizing values, requirements and strategy and whether to proceed with the project based on utilization of the opportunity space just to mention a few. Meaning, that public building projects within the Oslo municipality or municipalities with a similar investment regime, have already implemented most of these TVD characteristics. Though, besides from one characteristic involving the Allowable Cost. AC is not stated as a maximum for which the validation (or the pre-project) is based on.

For example, case 1,2 and 5 are based on a 3 years old school needs plan which include rough cost estimates. These estimates are based on sketches provided in the basis for concept choice and therefore define the units which can be estimated. In other words, the cost estimates (which cannot be compared to AC) are conducted, though in a "light version" of bottom-up estimation. Within the TVD methodology, this process should be conducted top-down by identifying project targets (Ballard and Morris 2010; Simonsen et al. 2019). Case 1, which stands out in regard of cost estimation, conducted an estimation process based on historical price data and a lot of assumptions at the start of the preproject. This process revealed one of the challenges of conducting an early estimate: The dependency of feedback from the client and the user(s). Meaning, that the client and the user(s) must even earlier know project-specific elements of importance. Benchmarking is in this regard an important element in the early phase of the cost estimation processes. For both case 1 and 2, this cost pressure resulted in a unified process to conduct cost reductions within the stated project assumptions. Otherwise, the project would not be executed. One must have in mind that the projects needed to conduct some fundamental changes in regard of the overall structure, layout and landscaping, and that these changes might have an impact on the delivered project value. Currently, the focus towards achieving project cost needs to be evolved to implement other values. Case 3 and 4 are examples of projects where environmental and safety aspects were prioritized before cost. Even so, the stated prioritized outputs in the steering document in regard of the two projects indicate inconsistency. One could possibly argue that the outcome to achieve the first BREEAM Excellent nursing home and to build the most environmental-friendly nursing home in the country cannot coincide with cost being the prioritized output.

\section{Defining (validation)}

The validation process, which often concurs with the purpose of the pre-project, focus towards developing and creating a common understanding among the involved actors of the: 1) basis of design, 2) basis of budget, and 3) basis of operation (Lee et al. 2012).

Target setting is supposedly related to value, but the interviews uncovered that too often decisions are being made purely based on cost. An important element in the evaluation process for case 3 of the delivered tenders was the distance between different functions and the residential units within the nursing home. Which is of importance due to the worker-patient ratio. These distances were transformed and calculated based on 
operational costs. Furthermore, this case had a predetermined Target Cost for each nursing home spot. In other words, the characteristic of benchmarking has already been achieved since this Target Cost is equal within the Oslo municipality. However, this Target Cost is based on certain assumptions, and if these assumptions do not correspond to the given project, the cost should be adjusted accordingly. These assumptions could not be identified and clarified which provided unnecessary work for the project management in order to provide these clarifications. In order to have a realistic Target Cost, project specific elements must be compared to its peer groups and there is a need for transparency for either targeting a lower cost based on current best practice or to deliver a target scope greater than current best practice within the project budget. Another stated outcome for the project is to include automation and the use of welfare technology to increase the safety and to lower the operational costs. Project value is therefore linked to creating an efficient and worthy health care experience for the residents. An element which differs from case 3 is the implementation of a gradually maturing of the TC for case 4 . Intentionally, by having four stage-gates with a delivery of a contractual TC the client forced the contractor to further develop the project within the previous delivery. Theoretically, this should result in a gradually increase of maturity/detailing and a reduction of risk. Each milestone was also based on tenders from the sub-contractors and -suppliers. At the last milestone the EC increased which can be seen in Figure 3. This development is explained by the PM to be related to the contractor's need to limit risk and exposure. Even though the final EC was set at the last milestone, some elements were deliberately left out of the tender due to the faith in further technological development. Doing so, follows the SBD methodology for optimizing the project value.

\section{Steering}

An important aspect when discussing the time frame of a decision, is the "distance" between the project organization and the decision-making authority. For case 3 and 4 the PM had expanded authority which resulted in more rapid decisions. As of case 1, 2 and 5 the PMs did not have any authority which influenced the decision basis in the different cases varies. Case 1 was highly affected by the focus towards cost reduction due to increased project scope and unexpected cost overrun regarding groundwork. As stated by the interviewees they had to satisfy the minimum criteria or functions in a cost-efficient manner. This provided a baseline. These evaluations were not based on a priority list but from identified or previous experienced cost drivers. "Good enough" was the key phrase in this process. Solutions related to cost drivers and the minimum criteria or functions stated in the tender documents, were further developed during the pre-project. "Need to have vs. nice to have" is also a statement of great interest. A specific focus towards value drivers have not been uttered. Even though the outcomes focus toward a forward-looking facility and the achievement of climate and energy objectives just to mention a few, the focus seem to be at achieving the outputs of cost and time.

Through monthly reporting the PM and the contractor (with his own monthly reports) have had an up-to-date indication of accumulated project cost, adjusted TC (due to changes) and the estimated cost of completion alongside EC and AC. The characteristic of rapid iterations is fulfilled in these cases.

One interesting finding in the manner of changes and optimizations was the contractor in case 1 that stated if the reduction of operating cost is the primary cause for the client to improve a function, then it should be defined as a 'change'. Since the optimization is not within the lifetime of the project which the contractor is a part of. 
Furthermore, other elements have been included in the decision-making basis for the other cases. Time and cost consequences were the most important elements in the decision-making basis for case 2. Looking at the stated tasks for the PM in case 3, one gets the impression of the implementation of some of the TVD characteristics. Case 4 aims towards becoming the most environmental-friendly nursing home in the country. Environmental elements are therefore in the decision-making basis.

\section{CONCLUSION AND FURTHER RESEARCH}

The purpose of this paper was to explore the use of TVD in the early phases of public building projects, and to answer the RQ: How is the TVD maturity in the Norwegian Construction Industry?

Based on findings in the literature and case studies, TVD maturity in the Norwegian Construction Industry varies. TVD characteristics within contracting, organizing, defining and steering are only partially implemented. TVD strengthen the focus towards achieving targets within project constraints during the pre-project. Enhancing maximum project value is a challenge in the some of the cases due to the lack of visualization and the focus towards cost reduction. A structured decision-making process which implements 'the best of both worlds' is a possible improvement from current decisionmaking processes in order to adapt the business case towards project constraints. Decision-making based on identified cost drivers must embrace project value:

- In general, a decision-making process must reflect when a decision is being made, the decision basis and what the consequences are for the client and the contractor.

- TVD methodology can be included in the decision-making basis by stating TC based on project constraints and objectives before the pre-project phase. Both the validation and steering must reflect the 'nice to have' vs. 'need to have'-mentality.

More focus towards the root causes is necessary in order to fully understand the implications of adapting these methods. Difficulties in order to verify and control if the cost reduction correlates to a reduction in project value is an area of improvement.

\section{REFERENCES}

Bakke, C., Johansen, A., Mahmood, K. M., and Grenland, S. 2019. Feeble Project Mandate equal higher cost? Procedia Computer Science. 164, 433-440. https://doi.org/10.1016/j.procs.2019.12.203

Ballard, G. 2008. "The lean project delivery system: An update”, The Lean Construction Journal, pp. 1-19. https://www.leanconstruction.org/learning/publications/lean-constructionjournal/lcj-back-issues/2008-issue/.

Ballard, G. and Morris, P. 2010. "Maximizing owner value through target value design", Research-Gate. https://www.researchgate.net/publication/281925177

Ballard, G. and Pennanen, A. 2013, 'Conceptual Estimating and T.arget Costing' In: Proc. $21^{\text {th }}$ Ann. Conf. Int. Group for Lean Construction, Fortaleza, Brazil, pp 217-226.

Ballard, G. and Rybkowski, Z. K. 2009. "Overcoming the hurdle of first cost: Action research in target costing." Proc. Construction Research Congress 2009: Building a Sustainable Future. Seattle, United States, 5-7 Apr 2009.

Chen, D.D., Ballard, G., and Tommelein, I. 2014. "Target value design as a method for controlling project cost." Proc. $22^{\text {nd }}$ Ann. Conf. Int. Group for Lean Constr., Oslo, Norway, pp. 171-181.

Chih, Y.-Y. and Zwikael, O. 2014. "Project benefit management: A conceptual framework of target benefit formulation." Int. Journal of Project Management 33, 352-362. https://doi.org/10.1016/j.ijproman.2014.06.002. 
Creswell, J. W. (2003). Research Design: Qualitative, Quantitative and Mixed Methods Approaches. USA: Sage Publications.

Feil, P., Yook, K.-H. and Kim, I.-W. 2004. "Japanese target costing: A historical perspective." International Journal of Strategic Cost Management. https://uakron.edu.

Lee, H. W., Ballard, G., Tommelein, I. D. and Larson, R. (2012). Application of Target Value Design to Energy Efficiency Investments, $\mathrm{PhD}$ thesis, University of California, Berkeley.

Namadi, S. A., Pasquire, C. and Manu, E. 2017. "Discrete costing versus collaborative costing", In: Proc. $25^{\text {th }}$ Ann. Conf. Int. Group for Lean Construction, Heraklion, Greece, pp. 3-10.

Nguyen H.V., Tommelein I.D and Ballard G. 2008. "Process-based cost modelling to support Lean Project Delivery". Proc. $16^{\text {th }}$ Ann. Conf. Int. Group for Lean Construction (IGLC). Manchester, United Kingdom, 16-18 Jul 2008. pp 577-588.

Pennanen, A., Ballard, G. and Haahtela, Y. 2010. "Designing to Targets in a Target Costing Process." Proc. $18^{\text {th }}$ Ann. Conf. Int. Group for Lean Construction, Haifa, Israel, pp. 161-170.

PMI 2013. A Guide to the Project Management Body of Knowledge (PMBOK Guide). Fifth. Ed. USA: Project Management Institute, Inc

Samset, K. F., Volden, G. H., Olsson, N. and Kvalheim, E. V. 2015. Governance schemes for major public investment projects: A comparative study of principles and practices in six countries. Trondheim, NO: Concept.

Serra, C. E. M. and Kunc, M. 2015. "Benefits realisation management and its influence on project success and on the execution of business strategies", International Journal of Project Management 33, 53-66. https://doi.org/10.1016/j.ijproman.2014.03.011.

Simonsen, S.H.F., Skoglund, M.H., Engebø, A., Varegg, B.E. and Lædre, O. 2019. "Effects of IPD in Norway-a case study of the Tønsberg project." Proc. $27^{\text {th }}$ Ann. Conf. Int. Group for Lean Construction (IGLC). Dublin, Ireland, 1-5 Jul 2019. pp. 251-262.

Tillmann P. A., Do Doanh; Ballard, G. 2017. "A case study on the success factors of Target Value Design." Proc. $25^{\text {th }}$ Ann. Conf. Int. Group for Lean Construction, Heraklion, Greece, pp. 563 $-570$.

Torp, O. 2019. "How stochastic cost estimates could be applied in relation to target value design." In: Proc. $27^{\text {th }}$ Ann. Conf. Int. Group for Lean Construction.

Torp, O., Belay, A., Thodesen, C. and Klakegg, O. J. 2016. "Cost Development Over-time at Construction Planning Phase: Empirical Evidence from Norwegian Construction Projects." Procedia Engineering. 145, 1177-1184. https://doi.org/10.1016/j.proeng.2016.04.152

Ulstein, H., Wifstad, K., Seeberg, A. R., Hardersen, R. and Løken, A. M. 2015. Kostnadsutvikling mellom KS1 og KS2 i byggeprosjekter [in Norwegian]. Oslo, NO: Menon Business Economics.

Welde, M., Aksdal, J. and Grindvoll, I. L. T. 2015. Kommunale investeringsprosjekter, prosjektmodeller og krav til beslutningsunderlag [in Norwegian]. Trondheim, NO: Concept.

Yin, R.K. (2018). Case study research and application: design and methods. $6^{\text {th }}$ ed. USA: Sage Pubs.

Zimina, D., Ballard, G. and Pasquire, C. 2012. "Target value design: using collaboration and a lean approach to reduce construction cost." Construction Management and Economics. https://doi.org/10.1080/01446193.2012.676658.

Zwikael, O. and Smyrk, J. 2012. "A general framework for gauging the performance of initiatives to enhance organizational value." British Journal of Management. 23, 6-22. https://doi.org/10.1111/j.1467-8551.2012.00823.x. 